\title{
Persistent organochlorine pesticide residues in cocoa beans from Ghana, a concern for public health
}

\author{
Elvis D. Okoffo, Benedicta Y. Fosu-Mensah* and Christopher Gordon
}

\begin{abstract}
Background: Residual levels of fifteen (15) organochlorine pesticides were determined in 32 cocoa bean samples collected from sixteen (16) selected cocoa farms in the Dormaa West District of Ghana to assess the levels of pesticides contamination.

Results: The results show that all cocoa bean samples analysed from the study area had one or more organochlorine pesticide residues detected in them. The study revealed the presence of eight organochlorine pesticide residues in the cocoa bean samples analysed at varying concentrations. The organochlorine pesticide residues detected were aldrin $(0.02-0.03 \mathrm{mg} / \mathrm{kg})$, dieldrin $(0.02-0.04 \mathrm{mg} / \mathrm{kg})$, lindane $(0.03-0.05 \mathrm{mg} / \mathrm{kg})$, beta-HCH $(0.02-0.03 \mathrm{mg} / \mathrm{kg}), p, p^{\prime}-\mathrm{DDE}(0.02-0.03 \mathrm{mg} / \mathrm{kg}), p, p^{\prime}-\mathrm{DDD}(0.02-0.04 \mathrm{mg} / \mathrm{kg}), p, p^{\prime}$-DDT $(0.04-0.05 \mathrm{mg} / \mathrm{kg})$ and methoxychlor $(0.02-0.04 \mathrm{mg} / \mathrm{kg})$. The most frequently found and abundant pesticide residue was the metabolite of DDT ( $\left.p, p^{\prime}-\mathrm{DDT}\right)$ which occurred in $62.5 \%$ of the samples, followed by lindane $(56.3 \%)$ and then beta-HCH and $p, p^{\prime}$-DDD occurring in $50 \%$ of the samples. None of the detected pesticide mean residues recorded from the various study sites exceeded their European Union (EU) Maximum Residue Limits (MRLs) for cocoa beans except beta-HCH at Krakrom (S3).

Conclusion: The levels of organochlorine pesticide residues in the fermented dried cocoa beans analysed compared to the European Union (EU) commission regulations on pesticide residues showed no health risks to consumers of cocoa beans from Ghana and no threat to cocoa export to Europe. The occurrence of organochlorine pesticide residues in the samples analysed could be due to their illegal use by farmers in the study area or due to their past use, since these chemicals are prohibited from agricultural use in Ghana. There should be regular monitoring of pesticide residues especially in cocoa beans to protect consumers from health related risks. There is a need to check and enforce regulations on the use of banned/restricted and unapproved pesticides in cocoa production in Ghana.
\end{abstract}

Keywords: Cocoa beans, Pesticide residues, Organochlorine, Health risks, Environment

\section{Background}

Pests and diseases are recognised as a major factor responsible for the decline in crop productivity, particularly cocoa yield in Ghana. This has resulted in increased use of pesticides in an effort to increase productivity. However, the regular application and indiscriminate use of these chemicals can have unintended environmental and human health consequences. Generally, pesticides are broadly divided into many classes of

\footnotetext{
* Correspondence: yayramensah@staff.ug.edu.gh

Institute for Environment and Sanitation Studies (IESS), University of Ghana, P. O. Box 209, Legon, Accra, Ghana
}

(C) 2016 The Author(s). Open Access This article is distributed under the terms of the Creative Commons Attribution 4.0 International License (http://creativecommons.org/licenses/by/4.0/), which permits unrestricted use, distribution, and reproduction in any medium, provided you give appropriate credit to the original author(s) and the source, provide a link to the Creative Commons license, and indicate if changes were made.

which the most important are the organochlorine pesticides (Adeyemi et al. 2011; Kuranchie-Mensah et al. 2012). Organochlorine pesticides (OCs) which are among the agrochemicals that have been used extensively for long period in Ghana (Clarke et al. 1997), particularly in cocoa production are broad spectrum synthetic organic pesticides which are made up of predominantly carbon, hydrogen, chlorine and sometimes oxygen (Afful et al. 2010; Frimpong et al. 2012a; Idowu et al. 2013; Asiedu 2013). They are composed of three broad groups or types namely; dichlorodiphenylethanes (DDT) and analogues, cyclodienes and the chlorinated benzenes or cyclohexane's (Asiedu 2013). Organochlorine pesticides that have been

\section{Springer Open}


widely used in cocoa production in Ghana include aldrin/ dieldrin, chlordane, DDT, endrin, hexachlorobenzene, endosulfan, methoxychlor, lindane, diazinon and heptachlor (Afful et al. 2010; Owusu-Ansah et al. 2010; Frimpong et al. 2012a; Frimpong et al. 2012b; Kuranchie-Mensah et al. 2012).

Organochlorine pesticides break down slowly and can persist in the environment long after application and in organisms long after exposure (Botwe 2007; Dikshith 2008; Darko et al. 2008). They have the tendency for long range transport and trans-boundary dispersions, and their capacity to bio-accumulate in the food chain poses a great threat to the environment, wildlife and humans (Ntow 2005; Darko et al. 2008; Frimpong et al. 2012a; Frimpong et al. 2012b). They are lipophilic and may bio-accumulate in the fatty parts of biological beings such as breast milk, blood and fatty tissues when small amounts are taken up in food (William et al. 2008). Exposure to organochlorines through the consumption of a crop that has organochlorine residues may cause acute and chronic toxicities. Organochlorine pesticides have become ubiquitous contaminants and have been implicated in a wide range of adverse health effects in laboratory animals and humans (Adeyemi et al. 2011). These toxic effects include reproduction and birth defects/failures, deformities, neurological damage, immune system dysfunction, endocrine disruptions, and cancer (Ahlborg et al. 1995; Amoah et al. 2006; Sosan et al. 2008; Leena et al. 2012).

Although the agricultural use of organochlorine pesticides have been banned or seriously restricted in many developed nations and some developing countries like Ghana (due to their adverse effects on human health and persistence in the environment) (Darko et al. 2008; Botwe et al. 2012), there are evidences of their continuous use on crops particularly cocoa trees, vegetables and fruits, among others (Botwe 2007; Darko and Acquaah 2007; Darko et al. 2008; Bempah and Donkor 2011; Asiedu 2013). The continuous use of these chemicals may be due to a combination of factors including inadequate regulation and management, trade, weak enforcement of bans on pesticides importation, illegal use/application and lack of logistics to monitor these pesticides in Ghana.

Furthermore, the continuous use of these chemicals may be due to their effectiveness in controlling pest and diseases, low cost, their versatility against various pests, their availability as well as ignorance of their harmful effects by farmers in Ghana (Bempah et al. 2011b). According to Asiedu (2013), already-made pesticide formulations in soft drink bottles and other unlabelled liquid containers sold to farmers in Ghana may contain some of these restricted or banned pesticides. Research data available have indicated the presence of organochlorine pesticide residues in surface water and sediments (Darko et al. 2008; Kuranchie-Mensah et al. 2012), fruits and vegetables (Bempah and Donkor 2011; Bempah et al. 2011a; Bempah et al. 2011b; Asiedu 2013), meat (Darko and Acquaah 2007) and cocoa beans (Botchway 2000; Apau and Dodoo 2010; Agyen 2011; Daanu 2011; Boakye 2012; Frimpong et al. 2012a; Frimpong et al. 2012b) in Ghana, which are emanating from current and past use of these chemicals.

Recent changes in regulations in the European Union (EU), North America and Japan have called for a reflection on crop protection practices in cocoa and other commodity crops (International Cocoa Organization (ICCO) 2007). The quality of cocoa beans imported into the EU and elsewhere is assessed based on traces of pesticides and other substances that have been used in the supply chain (Afrane and Ntiamoah 2011). Cocoa beans that are found to contain traces of these substances above the Maximum Residue Levels (MRLs) are rejected, which reduces the value of cocoa beans produced form the producing nation. In 2010, over 20,000 MT of cocoa beans was rejected by Japan due to the presence of high pesticide residues (Kaminaga 2011). For instance, Sarfo (2013) reported that a 2,000 tonne shipment of cocoa bean to Japan from Ghana was rejected in 2006, due to the detection of illegal pesticide residues. Ghana therefore risks being blacklisted by its major foreign cocoa buyers, if immediate action is not taken to halt the trend which will impact negatively on Ghana's economy.

The Brong Ahafo region is one of the major cocoa producing regions in Ghana. However, over the years, pests and diseases have been a major factor responsible for the decline in cocoa yield in the region. The Dormaa West District is one of the major cocoa producing districts in the Brong Ahafo Region of Ghana. In order to increase cocoa productivity in the district, there has been an increased use of pesticides to control pests and diseases. This practice may however result in high levels of pesticide residues in cocoa beans and hence reduce its value. In addition, the regular application and indiscriminate use of these chemicals can have unintended environmental and human health consequences, particularly when residues of these chemicals are taken up by cocoa beans and ingested by humans. Unfortunately, there is little information on levels of organochlorine pesticide residues in cocoa beans produced from the district. This paper, therefore, seeks to assess the contamination levels of organochlorine pesticide residues in cocoa beans produced from the Dormaa West District of Ghana to ascertain the potential health risks of the general public.

\section{Methods}

Study area

The study was carried out in the Dormaa West District located at the western part of the Brong Ahafo Region of Ghana with slightly hilly terrain (240-300 m above sea 
level) (Fig. 1). It shares boundaries in the north with the Dormaa Central Municipality, in the east with Asunafo North Municipality, in the west with Côte d'Ivoire and in the south west with Bia East District (Ghana Statistical Service 2014). The district is generally an agrarian economy which contributes immensely to food security in the country. Agriculture is the main source of employment $(82 \%)$ in the district. The major economic activities in the district include the cultivation of food and cash crops (including cocoa), poultry and livestock farming, oil palm extraction, cassava processing and sand winning (Ghana Statistical Service 2014).

\section{Sampling design}

Four cocoa growing communities namely Nkrankwanta (S1), Diabaa (S2), Krakrom (S3) and Kwakuanya (S4) as shown in Fig. 1 were randomly selected from the district. Within each selected community, four cocoa farms were identified and selected. A total of sixteen (16) cocoa farms were selected with the age of the farm (farm not less than 8 years and not more than 20 years with a history of at least five years of pesticides application) and the density of cocoa production used as determining factors. Sampling of cocoa beans was done between December 2014 and February 2015.

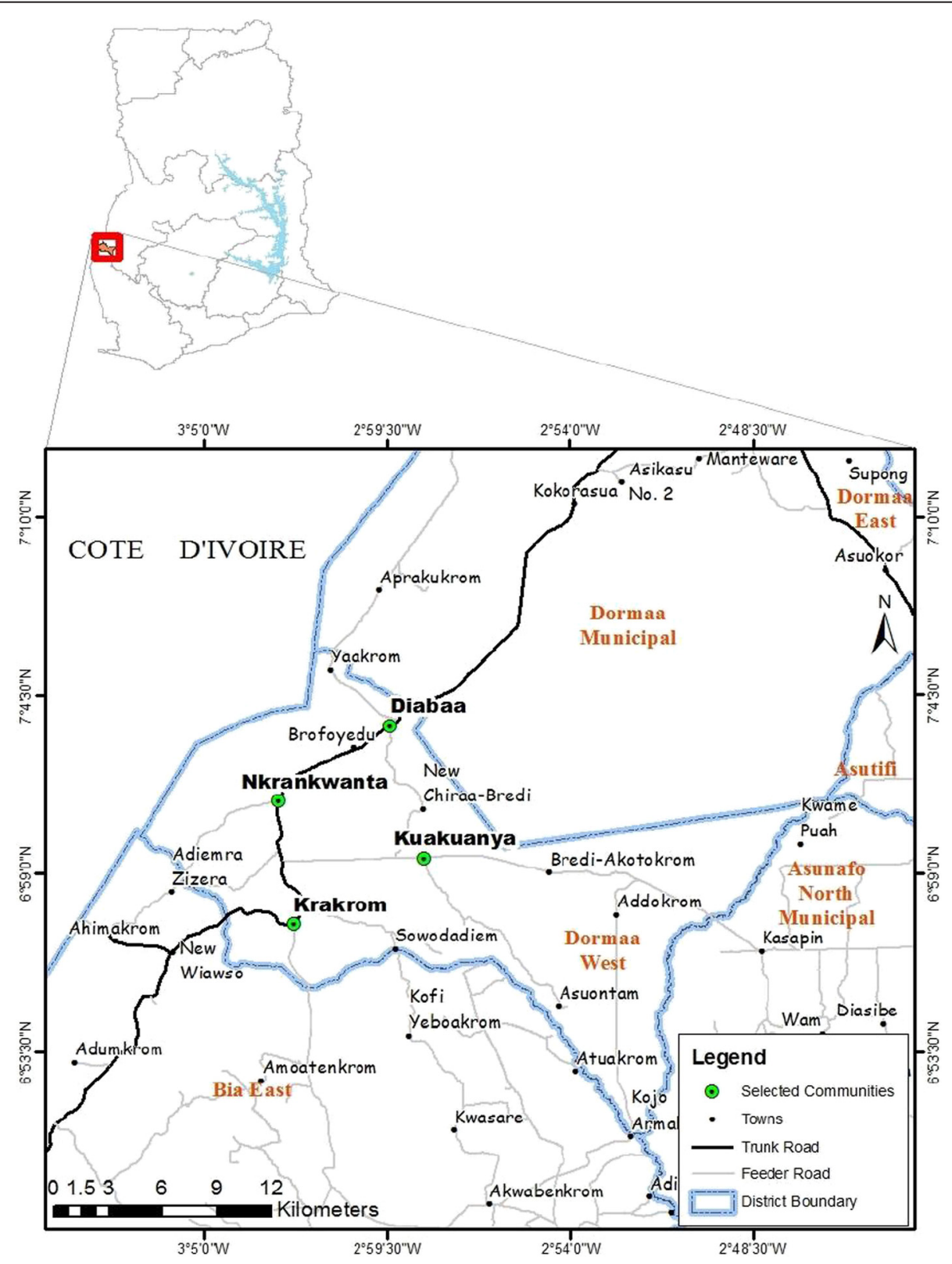

Fig. 1 Map of Dormaa West District showing selected communities 


\section{Sample collection}

Each selected cocoa farm was divided into two quadrats (80 x 80). Within each quadrat, five (5) cocoa trees were randomly selected, where five (5) matured and ripped cocoa pods were randomly taken and kept in labelled bags. Two replicates of cocoa bean pod were collected from each cocoa farm giving a total of 32 cocoa bean pods (samples) from the study area. The pods were transported to the laboratory [Ecological Laboratory (ECOLAB), of University of Ghana, Legon] where they were broken and the cocoa beans fermented for seven days. The fermented beans were sun-dried for 21 days and later oven dried at $60{ }^{\circ} \mathrm{C}$ for $5 \mathrm{~h}$ until a constant weight was attained. The dried cocoa beans from each quadrat of a farm were then bulked together to form a composite sample. The composite cocoa bean samples were well mixed and $2 \mathrm{~kg}$ sub-samples were taken into clean labelled polythene bags and transported to the Ghana Standards Authority Pesticide Residue Laboratory in Accra, Ghana for analysis. In the laboratory, samples were frozen in the refrigerator and analysed within a week.

\section{Sample preparation}

Samples of fermented dried cocoa beans $(2 \mathrm{~kg}$ ) were thoroughly grounded into fine powder and homogenized. Approximately $10 \mathrm{~g}$ of the sample were used for pesticide analysis.

\section{Chemicals and reagents used}

The individual certified organochlorine pesticide standards used for the identification and quantification $(\beta$ $\mathrm{HCH}, \gamma-\mathrm{HCH}, \delta-\mathrm{HCH}$, heptachlor, aldrin, $\gamma$-chlordane, $p, p^{\prime}$-DDE, $p, p^{\prime}-\mathrm{DDT}, p, p^{\prime}-\mathrm{DDD}$, dieldrin, endrin, $\alpha-$ endosulfan, $\beta$-endosulfan, endosulfan-sulfate and methoxychlor) were obtained from Dr. Ehrenstorfer $\mathrm{GmbH}$ (Augsburg, Germany) with certified purity of $98 \%$ and stored in the freezer to minimize degradation. Pesticide residue grade acetonitrile (99.5\%) was purchased from $\mathrm{BDH}$, England. ENVI-Carb/LC- $\mathrm{NH}_{2}(500 \mathrm{mg} / 500 \mathrm{mg} /$ $6 \mathrm{~mL}$ ) and Bond elute C-18 SPE cartridges (1000 mg / $6 \mathrm{~mL}$ ) were purchased from Supelco Inc., USA and Phenomenex, USA, respectively. All other reagents and solvents used for analysis were of analytical grade purchased from BDH, England and included: acetone, ethyl acetate (99.8\%), anhydrous sodium sulphate $\left(\mathrm{Na}_{2} \mathrm{SO}_{4}\right)$ and sodium chloride $(\mathrm{NaCl})$.

\section{Preparation of standard solutions}

Pesticides standard stock solutions $(1000 \mu \mathrm{g} / \mathrm{mL})$ of each of the certified reference organochlorine pesticide standards were prepared by pipetting the appropriate aliquot or weight of the certified reference pesticide into a $25 \mathrm{~mL}$ volumetric flasks, and then dissolving and diluting with ethyl acetate with the aid of a vortex mixer
(Thermolyne Maxi Mix-Plus). Stock solutions were stored in refrigerator. Working solutions of the pesticide standards for use as fortification standards in the procedural recovery process, and as calibration standards in the instrument calibration were freshly prepared through the dilution of an appropriate aliquot of the stock solutions with ethyl acetate.

\section{Analysis of organochlorine pesticide residues Extraction and clean up}

The Japanese multi-residue method for agricultural chemicals by GC/MS (agricultural products) released by the Department of Food Safety, Ministry of Health, Labour and Welfare (2006), (No. 0124001) as adapted in the Ghana Standard Authority (GSA) Pesticide Residues Laboratory Protocol were followed for extraction and clean-ups, with slight modifications. This method has been used by Frimpong et al. (2012a, b, c, d) to analysed pesticide residues in cocoa beans ready for export in Ghana.

Ten grams (10 g) of the homogenous cocoa bean subsamples were weighed into $250 \mathrm{~mL}$ Nalgene jars. A $20 \mathrm{~mL}$ of distilled water was added to each sample and left to stand for $15 \mathrm{~min}$. A $40 \mathrm{~mL}$ acetonitrile was added and homogenized using the Ultra Turrax T25 basic homogeniser (Staufen, Germany) for $2 \mathrm{~min}$. They were then centrifuged (Jouan CR3i multifunction) at a speed of $3000 \mathrm{rpm}$ for $3 \mathrm{~min}$ and decanted through filter papers into labelled $100 \mathrm{~mL}$ volumetric flasks. The extracts were placed back into the Nalgene jars and $20 \mathrm{~mL}$ acetonitrile was added, homogenized for $2 \mathrm{~min}$ and the dispersing element rinsed with $5 \mathrm{~mL}$ acetonitrile. The suspensions were then centrifuged (Jouan CR3i multifunction) at $3000 \mathrm{rpm}$ for $3 \mathrm{~min}$ and filtered into each corresponding labelled $100 \mathrm{~mL}$ volumetric flasks. A $15 \mathrm{~mL}$ acetonitrile was used to rinse the jars and residues filtered. All filtrates were made up to $100 \mathrm{~mL}$ with acetonitrile in the $100 \mathrm{~mL}$ volumetric flasks. Aliquot of $20 \mathrm{~mL}$ of the filtrates were pipetted into labelled $250 \mathrm{~mL}$ separating flasks, and $10 \mathrm{~g}$ of $\mathrm{NaCl}$ and $20 \mathrm{~mL}$ of $0.5 \mathrm{~mol} / \mathrm{L}$ phosphate buffer $(\mathrm{pH} 7.0)$ were added. The separating flasks were corked and shook for $20 \mathrm{~min}$ using the horizontal shaker (Ika-Werke HS 501 Digital) and left to stand for $10 \mathrm{~min}$ until the solutions were clearly separated into layers. The $\mathrm{NaCl}$ and lower aqueous layers in each separating flask were carefully removed and the organic layers (acetonitrile layers) transferred into labelled $50 \mathrm{~mL}$ beakers for clean-ups.

\section{First clean up using bond elute C-18 cartridges}

Bond elutes C-18 (1000 mg / 6 mL) cartridges were conditioned with $10 \mathrm{~mL}$ acetonitrile. Labelled $30 \mathrm{~mL}$ round bottomed flasks were placed under the cartridges to collect elutes. Sample extracts from the extraction stage 
were loaded onto each corresponding cartridge, and eluted with $2 \mathrm{~mL}$ acetonitrile. A $5 \mathrm{~g}$ portion of anhydrous $\mathrm{Na}_{2} \mathrm{SO}_{4}$ was placed on filter papers in funnels and the extracts dried over them. The receiving flasks were rinsed with acetonitrile and passed over the $\mathrm{Na}_{2} \mathrm{SO}_{4}$. Each filtrate was collected into a well labelled $100 \mathrm{~mL}$ round bottom flask and concentrated at $40{ }^{\circ} \mathrm{C}$ to dryness using the rotary evaporator (Bibby RE 200 and Buchi Ratovapor R-210). The residues were re-dissolved with $2 \mathrm{~mL}$ of acetonitrile in a ratio of $1: 3$ prior to the second clean-up step.

\section{Second clean up using ENVI-Carb/LC-NH $\mathrm{N}_{2}$ cartridges} ENVI-Carb/LC- $\mathrm{NH}_{2}(500 \mathrm{mg} / 500 \mathrm{mg} / 6 \mathrm{~mL})$ cartridges were conditioned with $10 \mathrm{~mL}$ acetonitrile. A $50 \mathrm{~mL}$ round bottomed flasks were placed under the cartridges, and the extracts from the previous clean-up step loaded onto the corresponding cartridges. The extracts were allowed to filter and the eluates collected. The cartridges were then eluted with $20 \mathrm{~mL}$ acetonitrile in four portions with intermittent vacuum. All filtrates were then transferred into $100 \mathrm{~mL}$ round bottomed flasks and concentrated at $40{ }^{\circ} \mathrm{C}$ to approximately $1 \mathrm{~mL}$ using the rotary evaporator (Bibby RE 200 and Buchi Ratovapor R-210). A $10 \mathrm{~mL}$ of acetone was added to the concentrated solution and concentrated/evaporated to dryness. The extracts were re-dissolved in $2 \mathrm{~mL}$ ethyl acetate by pipetting, and transferred into labelled $15 \mathrm{~mL}$ screw capped tubes, closed and placed in a freezer for at least $30 \mathrm{~min}$. The extracts were removed afterwards and immediately centrifuged (Jouan CR3i multifunction) at $3000 \mathrm{rpm}$ for $5 \mathrm{~min}$, and the top layers carefully transferred into labelled $2 \mathrm{~mL}$ GC standard opening vials prior to quantification by Gas Chromatography (GC) equipped with $\mathrm{Ni}$ electron capture detector (ECD). All extracts were kept frozen until quantifications were achieved.

\section{Chromatographic conditions for organochlorine pesticides determination}

The final extracts were analysed by a Gas Chromatography (GC) - Varian CP-3800 (Varian Association Inc. USA) equipped with ${ }^{63} \mathrm{Ni}$ Electron Capture Detector (GC-ECD) and Combi PAL auto sampler that allowed the detection of contaminants even at trace level concentrations from the matrix to which other detectors do not respond. The GC conditions and the detector response were adjusted so as to match the relative retention times and response as spelt out by Japanese analytical methods for agricultural chemicals. The GC conditions used for the analysis were capillary column (fused silica capillary) coated with VF- $5 \mathrm{~ms}(30 \mathrm{~m}+10 \mathrm{~m}$ EZ guard $\times 0.25 \mathrm{~mm}$ internal diameter, $0.25 \mu \mathrm{m}$ film thickness). The injector and detector-ECD temperatures were set at $270{ }^{\circ} \mathrm{C}$ and $300{ }^{\circ} \mathrm{C}$, respectively. The oven temperature was programmed as follows: $70{ }^{\circ} \mathrm{C}$ held for $2 \mathrm{~min}$, ramped at $25{ }^{\circ} \mathrm{C} \mathrm{min}-1$ to $180{ }^{\circ} \mathrm{C}$, held for $1 \mathrm{~min}$, and finally ramped at $5{ }^{\circ} \mathrm{C} \mathrm{min}^{-1}$ to $300{ }^{\circ} \mathrm{C}$. Nitrogen was used as carrier gas at a constant flow rate of $1.0 \mathrm{~mL} \mathrm{~min}{ }^{-1}$ and detector make-up gas of $29 \mathrm{~mL} \mathrm{~min}^{-1}$. The injection volume of the $\mathrm{GC}$ was $1.0 \mu \mathrm{L}$. The total run time for a sample was $31.4 \mathrm{~min}$.

\section{Quantification and limit of reporting}

An external standard method using peak area was employed in the determination of the quantities of residues in the sample extracts. A standard mixture of known concentration of organochlorine pesticides was run and the response of the detector for each compound ascertained. The area of the corresponding peak in the sample was compared with that of the standard and the peak areas whose retention times coincided with the standards were extrapolated on their corresponding calibration curves to obtain the concentration. All analyses were carried out in triplicates and the mean concentrations computed accordingly.

The limit of reporting of the residues determined was based on the extract of the fortified samples that were serially diluted by factor of two to give different concentrations. One out of each concentration that gave a response three times the standard deviation of the least fortified sample was noted. This was used to estimate the statistical significance of differences between low level analyte responses and the combined uncertainties in both the analyte and the background measurement. The limit of reporting for the organochlorine pesticide residues was $0.005 \mathrm{mg} / \mathrm{kg}$.

\section{Quality control and quality assurance}

Quality control and quality assurance were incorporated in the analytical scheme. To ensure the validity of results, the following measures were taken. All glass ware used for analysis (extraction and clean ups) were rigorously washed with detergent and tap water. They were then rinsed with distilled water, thoroughly rinsed with analytical grade acetone and dried overnight in an oven at $150{ }^{\circ} \mathrm{C}$. The glass ware were then removed from the oven and allowed to cool down and stored in dust free cabinets.

The quality of organochlorine pesticide residues was assured through the analysis of solvent blanks, procedural matrix blanks and triplicate samples. All reagents used during the analysis followed the same extraction procedures. Solvent used were run to verify any interfering substances within the runtime. Prior to sample analysis, standards for all 15 organochlorine pesticides were analysed to verify adequate system performance. There was satisfactory agreement of data with analysed 
standards prior to sample analyses and between sample runs. In order to prevent background contamination, reagent blank in triplicate were included in each batch of sample analysis and three spiked samples in triplicate were also done to confirm satisfactory pesticide recovery. No organochlorine pesticide residues were detected in the blank for each extraction procedure. A fortification level of $0.005 \mathrm{mg} / \mathrm{kg}$ of standard mixtures was chosen based on the limit of reporting of the pesticide residues before analysis to evaluate the recovery of compounds in the cocoa bean samples analysed. Fortified samples were determined with good recoveries. Procedural recoveries were analysed concurrently with each batch of analytical extracts.

In addition, recalibration curves were run with each batch of sample to check that the correlation coefficient was kept above $r^{2}>0.995$. All analyses were carried out in triplicates and the mean concentrations were calculated based on the number of samples that tested positive to each residue. The efficiency of the analytical methods (the extraction and clean-up methods) was determined by recoveries of internal standards. The recoveries of the internal standards ranged between 70 and $98 \%$ for all the pesticide residues detected which shows that the method used is reproducible.

\section{Data analysis}

Statistical Package for Social Sciences (SPSS) software version 20.0 was used to determine the means and standard deviation for the pesticide residues detected in the cocoa bean samples. One-way Analysis of variance (ANOVA) was used to test for the significant differences and similarities between the pesticide residues detected in cocoa beans from the various sampled sites. Differences were considered significant at $p<0.05$.

\section{Results and discussion}

The monitored organochlorine pesticides were $\beta-\mathrm{HCH}$, $\gamma$ - $\mathrm{HCH}, \delta$ - $\mathrm{HCH}$, heptachlor, $\gamma$-chlordane, $p, p^{\prime}$-DDE, $p, p^{\prime}-$ DDD, $p, p$ - DDT, aldrin, dieldrin, endrin, $\alpha$-endosulfan, $\beta$-endosulfan, endosulfan-sulfate and methoxychlor. However, cocoa bean samples analysed from the study area showed the presence of eight (8) organochlorine pesticide residues (lindane (gamma- $\mathrm{HCH}$ ), beta- $\mathrm{HCH}$, dieldrin, aldrin, $p, p^{\prime}-\mathrm{DDE}, p, p^{\prime}-\mathrm{DDD}, p, p^{\prime}-\mathrm{DDT}$, and methoxychlor) as shown in Tables $1,2,3,4$ and 5 . The results show that all cocoa bean samples analysed were contaminated with one or more pesticide residue. The most frequently encountered pesticide residue was $p, p$ 'DDT; which was detected in 20 (62.5\%) out of the 32 samples of the analysed cocoa beans. Cocoa beans samples from S1, S2 and S3 recorded the highest number of different pesticide residues. Each recorded the presence of 7 different pesticide residues.
Lindane (gamma-HCH) occurred in $56.3 \%$ of the cocoa bean samples analysed and ranged from $0.03 \mathrm{mg} /$ $\mathrm{kg}$ at $\mathrm{S} 1$ and $\mathrm{S} 4$ to $0.05 \mathrm{mg} / \mathrm{kg}$ at $\mathrm{S} 3$ with a mean value of $0.04 \pm 0.01 \mathrm{mg} / \mathrm{kg}$. There were no significant differences $(p>0.05)$ in mean values of lindane among the sampled sites. The measured concentrations of lindane were far less than the European Union (EU) Maximum Residue Limit (MRL) of $1.00 \mathrm{mg} / \mathrm{kg}$ for cocoa beans.

Although gamma- $\mathrm{HCH}$ is the isomer of $\mathrm{HCH}$ that possesses high pesticidal activity, beta- $\mathrm{HCH}$ was also detected in $50 \%$ of the cocoa bean samples with a mean value of $0.02 \pm 0.00 \mathrm{mg} / \mathrm{kg}$. Its concentration value ranged from $0.02 \mathrm{mg} / \mathrm{kg}$ at $\mathrm{S} 1$ and $\mathrm{S} 2$ to $0.03 \mathrm{mg} / \mathrm{kg}$ at S3. Similarly, there were no significant differences $(p>$ $0.05)$ in mean values of beta- $\mathrm{HCH}$ among the sampled sites. The mean concentrations of beta- $\mathrm{HCH}$ recorded in this study were below the EU MRL of $0.02 \mathrm{mg} / \mathrm{kg}$ for cocoa beans with the exception of S3. In addition, the mean residue concentration of beta- $\mathrm{HCH}$ recorded in this study was comparable to the EU MRL of $0.02 \mathrm{mg} /$ $\mathrm{kg}$ for cocoa beans.

The presence of gamma-HCH and beta- $\mathrm{HCH}$ suggests previous/historical and/or current illegal use of technical $\mathrm{HCH}$ pesticide in the study area, since its use has been banned in cocoa production in Ghana. Lindane was marketed in Ghana as Gammalin 20 and was widely used on cocoa plantations until 2007 when it was banned for agricultural purposes due to their persistence and toxicity to untargeted organisms (Afful et al. 2010; Agbeve et al. 2014). The mean lindane concentration observed in this study was higher than the mean concentrations of $0.01 \mathrm{mg} / \mathrm{kg}, 0.01 \mathrm{mg} / \mathrm{kg}, 0.01 \mathrm{mg} / \mathrm{kg}$ and $0.0001 \mathrm{mg} / \mathrm{kg}$ reported by Botchway (2000), Frimpong et al. (2012a), Frimpong et al. (2012b), and Olayinka (2013) in cocoa bean samples, respectively. However, the mean lindane concentration observed in this study was lower than the concentration of $0.411 \mathrm{mg} / \mathrm{kg}$ reported by Apau and Dodoo (2010) in cocoa beans from the Central Region of Ghana. The findings of lindane in this study was contrary to that of Owusu-Ansah et al. (2010) which recorded no lindane residue in cocoa beans from the Twifo Praso district of Ghana. This could be due to none use of pesticides containing lindane as active ingredient in cocoa production in the district. On the other hand, the mean value of beta- $\mathrm{HCH}$ recorded in this study was higher than the mean value of $0.01 \mathrm{mg} / \mathrm{kg}$ reported by Frimpong et al. (2012b) in cocoa beans ready for export in Ghana. Also the findings of beta- $\mathrm{HCH}$ in this study was in line with those reported by Boakye (2012) and Frimpong et al. (2012a) in cocoa beans analysed from Ghana.

Aldrin is readily converted to dieldrin (once it enters either the environment or the body), which is considered one of the most persistent of all pesticides (Miles et al. 
Table 1 Concentrations of organochlorine residues $(\mathrm{mg} / \mathrm{kg}$ ) in cocoa beans from farms in Nkrankwanta (S1)

\begin{tabular}{|c|c|c|c|c|c|c|c|c|c|c|}
\hline \multirow{2}{*}{$\begin{array}{l}\text { Sites } \\
\text { Pesticides }^{c}\end{array}$} & \multicolumn{2}{|l|}{ FARM 1} & \multicolumn{2}{|l|}{ FRAM 2} & \multicolumn{2}{|l|}{ FARM 3} & \multicolumn{2}{|l|}{ FARM 4} & \multirow[b]{2}{*}{ Mean $^{a}$} & \multirow[b]{2}{*}{ EU MRL } \\
\hline & Farm 1A & $\overline{\text { Farm 1B }}$ & Farm 2A & $\overline{\text { Farm } 2 \mathrm{~B}}$ & Farm $3 \mathrm{~A}$ & Farm 3B & Farm 4A & Farm $4 \mathrm{~B}$ & & \\
\hline Lindane (gamma-HCH) & 0.01 & 0.03 & ND & ND & 0.03 & 0.03 & ND & ND & 0.03 & 1.00 \\
\hline Beta-HCH & ND & ND & 0.02 & 0.01 & 0.02 & ND & 0.02 & 0.01 & 0.02 & 0.02 \\
\hline Dieldrin & 0.01 & 0.02 & ND & ND & ND & 0.02 & ND & ND & 0.02 & 0.50 \\
\hline Aldrin & 0.01 & ND & ND & 0.02 & 0.01 & ND & 0.02 & ND & 0.02 & 0.05 \\
\hline$p, p^{\prime}-D D E$ & ND & 0.02 & 0.01 & 0.02 & ND & ND & ND & ND & 0.02 & 0.50 \\
\hline p,p'-DDD & ND & ND & ND & ND & ND & ND & ND & ND & ND & \\
\hline$p, p^{\prime}-D D T$ & 0.05 & 0.02 & 0.03 & 0.04 & 0.03 & 0.04 & ND & 0.04 & 0.04 & \\
\hline Methoxychlor & ND & ND & 0.02 & 0.04 & 0.04 & ND & 0.04 & 0.04 & 0.04 & 0.10 \\
\hline
\end{tabular}

ND Non-detected

${ }^{a}$ Mean of samples where residues were detected

${ }^{b}$ European Union maximum residue limits for pesticides in cocoa beans

cNumber of pesticides found in any sample

2009; Hogarh et al. 2014). These pesticides were used extensively in agriculture until their use was restricted. Although the use of aldrin and dieldrin is banned in many countries including Ghana, these pesticides were detected in the cocoa bean samples analysed from the study area. Aldrin was detected in $43.8 \%$ of the cocoa bean samples analysed and ranged from $0.02 \mathrm{mg} / \mathrm{kg}$ at $\mathrm{S} 1$ to $0.03 \mathrm{mg} / \mathrm{kg}$ at S3 and S4 with a mean value of $0.03 \pm 0.00 \mathrm{mg} / \mathrm{kg}$. There were no significant differences $(p>0.05)$ in mean values of aldrin among the sampled sites. The mean concentrations of aldrin recorded in this study were below the EU MRL of $0.05 \mathrm{mg} / \mathrm{kg}$ for cocoa beans. Similarly, its breakdown product, dieldrin, was recorded in $37.5 \%$ of the cocoa bean samples analysed with a mean value of $0.03 \pm 0.01 \mathrm{mg} / \mathrm{kg}$, which ranged from $0.02 \mathrm{mg} / \mathrm{kg}$ at S1 to $0.04 \mathrm{mg} / \mathrm{kg}$ at S2 and S3. Similarly, there were no significant differences $(p>0.05)$ in mean values of dieldrin among the sampled sites. The mean concentrations of dieldrin recorded in this study were below the EU MRL of $0.50 \mathrm{mg} / \mathrm{kg}$ for cocoa beans.
The occurrence of aldrin and dieldrin in the cocoa bean samples analysed suggests the illegal use of the pesticide (pesticides with aldrin and dieldrin as their active ingredient) by cocoa farmers in the study area, and/ or previous use of the chemicals, since their use for agricultural purposes has been banned in Ghana (Afful et al. 2010; Hogarh et al. 2014). In addition, the occurrence of dieldrin in the samples confirmed the possible degradation and/or metabolism of aldrin to dieldrin (which is stable, lipophilic and bioaccumulate in fats) in the environment. A similar observation was made by Boakye (2012). However, the relatively high percentage of cocoa beans $(43.8 \%)$ with detectable aldrin compared to samples $(37.5 \%)$ with detectable dieldrin, might also suggest a more or high input of aldrin at present than their degradation to dieldrin. The mean value of aldrin recorded in this study was higher than the mean values of $0.01 \mathrm{mg} / \mathrm{kg}$ and $0.01 \mathrm{mg} / \mathrm{kg}$ reported by Frimpong et al. (2012a) and Frimpong et al. (2012b), respectively, but lower than the $0.11 \mathrm{mg} / \mathrm{kg}$ reported by Daanu (2011) in

Table 2 Concentrations of organochlorine residues ( $\mathrm{mg} / \mathrm{kg}$ ) in cocoa beans from farms in Diabaa (S2)

\begin{tabular}{|c|c|c|c|c|c|c|c|c|c|c|}
\hline \multirow{2}{*}{$\begin{array}{l}\text { Sites } \\
\text { Pesticides }\end{array}$} & \multicolumn{2}{|l|}{ FARM 1} & \multicolumn{2}{|l|}{ FRAM 2} & \multicolumn{2}{|l|}{ FARM 3} & \multicolumn{2}{|l|}{ FARM 4} & \multirow[b]{2}{*}{ Mean $^{a}$} & \multirow[b]{2}{*}{ EU MRL ${ }^{b}$} \\
\hline & Farm 1A & Farm 1B & Farm 2A & Farm 2B & Farm 3A & Farm 3B & Farm 4A & Farm 4B & & \\
\hline Lindane (gamma-HCH) & 0.04 & ND & ND & ND & 0.01 & 0.04 & 0.05 & 0.04 & 0.04 & 1.00 \\
\hline Beta-HCH & 0.01 & 0.02 & ND & ND & 0.02 & 0.02 & 0.01 & ND & 0.02 & 0.02 \\
\hline Dieldrin & ND & ND & ND & 0.02 & 0.05 & 0.05 & ND & ND & 0.04 & 0.50 \\
\hline Aldrin & 0.03 & 0.03 & 0.03 & ND & ND & ND & 0.01 & 0.03 & 0.03 & 0.05 \\
\hline$p, p^{\prime}-D D E$ & ND & ND & ND & ND & ND & ND & ND & ND & ND & 0.50 \\
\hline$p, p^{\prime}-D D D$ & ND & ND & 0.01 & 0.04 & 0.04 & 0.04 & 0.04 & 0.04 & 0.04 & \\
\hline$p, p^{\prime}-D D T$ & 0.02 & 0.06 & 0.06 & ND & 0.06 & 0.05 & 0.04 & 0.06 & 0.05 & \\
\hline Methoxychlor & 0.01 & 0.02 & ND & 0.02 & 0.01 & 0.02 & ND & ND & 0.02 & 0.10 \\
\hline
\end{tabular}

ND Non-detected

${ }^{a}$ Mean of samples where residues were detected

${ }^{b}$ European Union maximum residue limits for pesticides in cocoa beans

${ }^{c}$ Number of pesticides found in any sample 
Table 3 Concentrations of organochlorine residues ( $\mathrm{mg} / \mathrm{kg}$ ) in cocoa beans from farms in Krakrom (S3)

\begin{tabular}{|c|c|c|c|c|c|c|c|c|c|c|}
\hline \multirow{2}{*}{$\begin{array}{l}\text { Sites } \\
\text { Pesticides }^{c}\end{array}$} & \multicolumn{2}{|l|}{ FARM 1} & \multicolumn{2}{|l|}{ FRAM 2} & \multicolumn{2}{|l|}{ FARM 3} & \multicolumn{2}{|l|}{ FARM 4} & \multirow[b]{2}{*}{ Mean $^{\mathrm{a}}$} & \multirow[b]{2}{*}{ EU MRL } \\
\hline & Farm 1A & $\overline{\text { Farm 1B }}$ & Farm2A & Farm 2B & Farm3A & Farm 3B & Farm 4A & $\overline{\text { Farm } 4 \mathrm{~B}}$ & & \\
\hline Lindane (gamma-HCH) & 0.01 & 0.05 & 0.06 & 0.05 & 0.04 & 0.06 & ND & ND & 0.05 & 1.00 \\
\hline Beta-HCH & 0.03 & 0.02 & 0.02 & ND & 0.02 & ND & 0.03 & 0.03 & 0.03 & 0.02 \\
\hline Dieldrin & 0.05 & 0.05 & ND & 0.01 & ND & ND & ND & ND & 0.04 & 0.50 \\
\hline Aldrin & ND & ND & ND & ND & ND & ND & ND & ND & ND & 0.05 \\
\hline$p, p^{\prime}-D D E$ & 0.01 & 0.03 & ND & ND & 0.03 & 0.03 & ND & ND & 0.03 & 0.50 \\
\hline$p, p^{\prime}-D D D$ & 0.03 & 0.03 & ND & 0.03 & ND & 0.03 & ND & 0.01 & 0.03 & \\
\hline$p, p^{\prime}-D D T$ & ND & 0.04 & 0.04 & 0.04 & 0.01 & ND & 0.04 & 0.04 & 0.04 & \\
\hline Methoxychlor & 0.03 & 0.01 & 0.03 & 0.03 & ND & ND & 0.03 & ND & 0.03 & 0.10 \\
\hline
\end{tabular}

ND Non-detected

${ }^{\mathrm{a}}$ Mean of samples where residues were detected

${ }^{b}$ European Union maximum residue limits for pesticides in cocoa beans

${ }^{\mathrm{c}}$ Number of pesticides found in any sample

cocoa beans from Ghana. Similarly, the mean value of dieldrin recorded in this study was higher than the mean values of $0.01 \mathrm{mg} / \mathrm{kg}$ and $0.02 \mathrm{mg} / \mathrm{kg}$ reported by Frimpong et al. (2012a) and Frimpong et al. (2012b), respectively in cocoa beans from Ghana. This could be due to the differences in the sampling methods used (in that, cocoa bean samples for this study was taken from cocoa farms while samples used in the other studies were taken from cocoa bean samples ready for shipment in Ghana) or differences in the area of which the cocoa beans were coming from.

$p, p^{\prime}$-DDE was detected in $34.4 \%$ of the samples analysed with a mean concentration of $0.02 \pm 0.00 \mathrm{mg} / \mathrm{kg}$. The measured concentrations ranged from $0.02 \mathrm{mg} / \mathrm{kg}$ at $\mathrm{S} 1$ and $\mathrm{S} 4$ to $0.03 \mathrm{mg} / \mathrm{kg}$ at S3. However, the differences in means were not statistically significant $(p>0.05) . p, p$ '- DDE, one of the metabolites of DDT is formed by the loss of hydrogen chloride (dehydrohalogenation) in DDT. They are fat soluble and have the capacity to build up in the fat of animals and humans, and are rarely excreted from the body
(Aikpokpodion et al. 2012). Studies have showed that exposure to $p, p$ - DDE can cause endocrine disruptions, oxidative stress, Alzheimer's and Parkinson's disease, contributes to breast cancer and damage the brain's dopaminergic system (Aikpokpodion et al. 2012). The mean concentration of $p, p^{\prime}-\mathrm{DDE}$ recorded in this study was lower than the mean value of $0.04 \mathrm{mg} / \mathrm{kg}$ reported by Aikpokpodion et al. (2012) in cocoa bean samples from three cocoa ecological zones in Nigeria, but higher than the $0.001 \mathrm{mg} / \mathrm{kg}$ reported by Frimpong et al. (2012a) in cocoa beans ready for export in Ghana. Also, the mean value of $p, p^{\prime}$ - DDE observed in this study was similar to the $0.02 \mathrm{mg} / \mathrm{kg}$ reported by Daanu (2011).

$p, p^{\prime}$-DDD residue was detected in $50 \%$ of the cocoa bean samples analysed with a mean value of $0.03 \pm$ $0.01 \mathrm{mg} / \mathrm{kg}$, which ranged from $0.02 \mathrm{mg} / \mathrm{kg}$ at $\mathrm{S} 4$ to $0.04 \mathrm{mg} / \mathrm{kg}$ at $\mathrm{S} 2$. There were no significant $(p>0.05)$ differences in mean values of $p, p^{\prime}$-DDD among the sampled sites. The mean $p, p^{\prime}$-DDD residue observed in this study was lower than the mean value of $0.15 \mathrm{mg} / \mathrm{kg}$

Table 4 Concentrations of organochlorine residues ( $\mathrm{mg} / \mathrm{kg}$ ) in cocoa beans from farms in Kwakwanya (S4)

\begin{tabular}{|c|c|c|c|c|c|c|c|c|c|c|}
\hline \multirow{2}{*}{$\begin{array}{l}\text { Sites } \\
\text { Pesticides } \\
\end{array}$} & \multicolumn{2}{|l|}{ FARM 1} & \multicolumn{2}{|l|}{ FRAM 2} & \multicolumn{2}{|l|}{ FARM 3} & \multicolumn{2}{|l|}{ FARM 4} & \multirow[b]{2}{*}{ Mean ${ }^{a}$} & \multirow[b]{2}{*}{ EU $M R L^{b}$} \\
\hline & Farm 1A & Farm 1B & Farm2A & Farm 2B & Farm3A & Farm 3B & Farm 4A & Farm 4B & & \\
\hline Lindane (gamma-HCH) & 0.03 & 0.04 & ND & ND & 0.01 & ND & ND & ND & 0.03 & 1.00 \\
\hline Beta-HCH & ND & ND & ND & ND & ND & ND & ND & ND & ND & 0.02 \\
\hline Dieldrin & ND & 0.03 & ND & ND & 0.02 & 0.03 & ND & ND & 0.03 & 0.50 \\
\hline Aldrin & 0.02 & 0.03 & 0.03 & ND & ND & ND & 0.02 & 0.03 & 0.03 & 0.05 \\
\hline$p, p^{\prime}-D D E$ & ND & ND & 0.01 & 0.02 & 0.02 & 0.02 & ND & ND & 0.02 & 0.50 \\
\hline$p, p^{\prime}-D D D$ & 0.03 & 0.01 & 0.01 & 0.02 & 0.03 & ND & ND & ND & 0.02 & \\
\hline$p, p^{\prime}-D D T$ & ND & ND & ND & ND & ND & ND & ND & ND & ND & \\
\hline Methoxychlor & ND & ND & ND & ND & ND & ND & ND & ND & ND & 0.10 \\
\hline
\end{tabular}

ND Non-detected

${ }^{a}$ Mean of samples where residues were detected

${ }^{b}$ European Union maximum residue limits for pesticides in cocoa beans

cNumber of pesticides found in any sample 
Table 5 Summary of organochlorine residues $(\mathrm{mg} / \mathrm{kg})$ in cocoa beans analysed from the study area

\begin{tabular}{|c|c|c|c|c|c|c|}
\hline Pesticides & Minimum & Maximum & Mean $^{\text {a }}$ & $\mathrm{SD}^{\mathrm{b}}$ & EU MRL ${ }^{c}$ & $\%$ Detected $^{d}$ \\
\hline Lindane (gamma-HCH) & 0.03 & 0.05 & 0.04 & 0.01 & 1.00 & $18(56.3)$ \\
\hline Beta-HCH & 0.02 & 0.03 & 0.02 & 0.00 & 0.02 & $16(50)$ \\
\hline Dieldrin & 0.02 & 0.04 & 0.03 & 0.01 & 0.50 & $12(37.5)$ \\
\hline Aldrin & 0.02 & 0.03 & 0.03 & 0.00 & 0.05 & $14(43.8)$ \\
\hline$p, p^{\prime}-D D E$ & 0.02 & 0.03 & 0.02 & 0.00 & 0.50 & $11(34.4)$ \\
\hline$p, p^{\prime}-D D D$ & 0.02 & 0.04 & 0.03 & 0.01 & & $16(50)$ \\
\hline p,p'-DDT & 0.04 & 0.05 & 0.04 & 0.00 & & $20(62.5)$ \\
\hline Methoxychlor & 0.02 & 0.04 & 0.03 & 0.01 & 0.10 & $10(31.3)$ \\
\hline
\end{tabular}

ND Non-detected

Limit of reporting $=0.005 \mathrm{mg} / \mathrm{kg}$

${ }^{a}$ Mean of mean values recorded for a pesticide residue for each sample site (mean ofsamples where residues were detected)

${ }^{\text {b}}$ Standard deviation of samples where residues were detected

${ }^{\mathrm{C}}$ European Union maximum residue limits for pesticides in cocoa beans

${ }^{\mathrm{d}}$ Number (\%) of samples with positive pesticide detections

reported by Aikpokpodion et al. (2012), but higher than the mean values of $0.01 \mathrm{mg} / \mathrm{kg}$ and $0.001 \mathrm{mg} / \mathrm{kg} \mathrm{re}-$ ported by Daanu (2011) and Frimpong et al. (2012a), respectively.

$p, p^{\prime}$-DDT was the most frequently detected residue in the samples analysed. It was observed in $62.5 \%$ of the samples and ranged from 0.04 at S1 and S3 to $0.05 \mathrm{mg} /$ $\mathrm{kg}$ at $\mathrm{S} 2$ with a mean value of $0.04 \pm 0.00 \mathrm{mg} / \mathrm{kg}$. There were no significant differences $(p>0.05)$ in mean values of $p, p^{\prime}$-DDT among the sampled sites. The mean value of $p, p^{\prime}$-DDT recorded in this study was higher than the mean values of $0.03 \mathrm{mg} / \mathrm{kg}$, $0.003 \mathrm{mg} / \mathrm{kg}$ and $0.01 \mathrm{mg} / \mathrm{kg}$ reported by Daanu (2011), Frimpong et al. (2012a) and Frimpong et al. (2012b), respectively. However, Aikpokpodion et al. (2012) recorded a mean $p, p^{\prime}$-DDT value of $0.06 \mathrm{mg} /$ $\mathrm{kg}$ which was higher than the mean value recorded in this study.

The concentrations of $p, p^{\prime}-\mathrm{DDE}, p, p^{\prime}-\mathrm{DDD}$ and $p, p^{\prime}-$ DDT expressed as total DDT in cocoa bean samples analysed ranged from $0.04 \mathrm{mg} / \mathrm{kg}$ at S4 to $0.10 \mathrm{mg} / \mathrm{kg}$ at S3 with a mean value of $0.07 \pm 0.02 \mathrm{mg} / \mathrm{kg}$. This average residue concentration of DDT ( $p, p^{\prime}-\mathrm{DDD}, p, p^{\prime}-\mathrm{DDE}$ and $p, p^{\prime}$-DDT) was by far lower than the EU MRL of $0.50 \mathrm{mg} / \mathrm{kg}$ for cocoa beans. The mean value of DDT recorded in this study was however higher than the mean values of $0.06 \mathrm{mg} / \mathrm{kg}, 0.006 \mathrm{mg} / \mathrm{kg}, 0.01 \mathrm{mg} / \mathrm{kg}$ and $0.0003 \mathrm{mg} / \mathrm{kg}$ reported by Daanu (2011), Frimpong et al. (2012a), Frimpong et al. (2012b) and Olayinka (2013), respectively, but lower than the mean value of $0.56 \mathrm{mg} /$ kg reported by Aikpokpodion et al. (2012).

DDT has been banned from agricultural use and restricted due to public health concern under the Stockholm convention in which Ghana is a signatory (Afful et al. 2010; Agbeve et al. 2014). Therefore, the occurrence of DDT and its metabolites in cocoa beans from the study area is an indication of the current illegal use of the pesticide by cocoa farmers in the study area. This is confirmed by the occurrence and high concentration of $p, p^{\prime}-\mathrm{DDT}$ compared to its metabolites $p, p^{\prime}-\mathrm{DDE}$ and $p, p^{\prime}-\mathrm{DDD}$, which is an indication that there might be recent input of DDT in the various cocoa plantations. The continues use of DDT products by the farmers could be due to their efficacy and lower price. It could also be that, new pesticides containing DDT as its active ingredient but un-familiar trade names were sold to the uninformed farmers. A similar observation was made by Aikpokpodion et al. (2012). Similarly, Adu-kumi et al. (2010) noted DDT contamination at some sampled sites in Ghana and attributed the presence to their recent use. However, the higher concentrations of DDT could also be attributed to the enormous past uses of the parent compound DDT and due to its longer half-life (i.e., slow degradation and its long term persistence in the environment).

Methoxychlor was detected in $31.3 \%$ of the cocoa bean samples analysed with a mean value of $0.03 \pm$ $0.01 \mathrm{mg} / \mathrm{kg}$, which ranged from $0.02 \mathrm{mg} / \mathrm{kg}$ at $\mathrm{S} 2$ to $0.04 \mathrm{mg} / \mathrm{kg}$ at $\mathrm{S} 1$. There were no significant differences $(p>0.05)$ in mean values of methoxychlor among the sampled sites. However, the observed methoxychlor concentrations were below the EU MRL of $0.10 \mathrm{mg} / \mathrm{kg}$ for cocoa beans. The presence of methoxychlor in the cocoa bean samples analysed suggests that methoxychlor had either been used on cocoa in the past (presence in the environment had not degraded) and/or currently illegally used, since they are banned for agricultural purposes in Ghana. In addition, the detection of methoxychlor may be either as a result of historical use of DDT of which technically methoxychlor contains about $88 \%$ of the $p, p$ 'isomer together with more than 50 structurally related contaminants, which might have been added to the actual amount of methoxychlor present (WHO 1996; Bempah and Donkor 2011; Agbeve et al. 2014). The mean value of 
methoxychlor recorded in the study was higher than the mean value of $0.002 \mathrm{mg} / \mathrm{kg}$ reported by Frimpong et al. (2012a) in cocoa beans from Ghana. However, the finding of methoxychlor in this study was contrary to the findings of Frimpong et al. (2012b) which reported no methoxychlor residue in cocoa beans ready for export in Ghana.

The presence of organochlorine pesticides in the cocoa beans samples analysed is a major concern due to the human health risks such as reproductive impairment and suppression of the immune system which can have long-term consequences for population viability. The contamination of the cocoa bean samples could have occurred directly by treating the crop with pesticides before harvest, where pesticide residues were adsorbed by the cocoa beans through the cocoa pod. In addition, the contamination may have occurred through the translocation of these chemicals from contaminated soil through the root system. However, the aforementioned might only hold for water soluble pesticides, since nonwater soluble pesticides remain in soil. These pesticides may run off to other areas and cause damage to untargeted animals and plants.

\section{Conclusion}

The results of this study revealed that cocoa bean samples from the study area were contaminated with organochlorine pesticide residues. Eight organochlorine pesticide residues namely, aldrin, dieldrin, lindane, beta$\mathrm{HCH}, p, p^{\prime}$-DDE, $p, p^{\prime}$-DDD, $p, p^{\prime}$-DDT and methoxychlor were detected in the cocoa bean samples analysed and were among the banned pesticides of the Environmental Protection Agency (EPA) of Ghana (Afful et al. 2010). $p, p$-DDT was the most frequently detected organochlorine pesticide residue. The occurrence of organochlorine pesticide residues in the samples analysed could be due to their illegal use by farmers or due to their previous use in cocoa production in the study area, since these chemicals are prohibited from agricultural use including cocoa production in Ghana. The observed mean values of all the pesticide residues detected in the cocoa beans analysed from the study sites were below their respective European Union Maximum Residue Levels for cocoa beans, with the exception of S3 which recorded mean concentration of beta-HCH to be above the EU MRL for cocoa bean. Considering levels of pesticide residues in the fermented dried cocoa beans against the European (EU) commission regulations on pesticide residues, cocoa beans analysed from the study area do not pose health risks and hence, threat to the cocoa industry in Ghana as far as export to Europe is concerned.

The enforcing agencies (Ministry of Agriculture, Ghana Cocoa Board (COCOBOD) and the Environmental Protection Agency of Ghana) should put in place more stringent measures to restrict the importation, sale and use of banned/restricted and unapproved pesticides in cocoa production in Ghana. Also, the National Cocoa Disease and Pest Control (CODAPEC) programme, popularly called "Mass spraying", (whose duty is to assist cocoa farmers in Ghana to combat pests and diseases on cocoa farms using the Ghana Cocoa board approved or recommended pesticides), must institute a monitoring mechanism to ensure that farmers who privately spray their farms do so with approved pesticides. In addition, cocoa farmers in the study area should be educated on the approved Ghana cocoa board pesticides to use on cocoa trees, the right amounts to use and the frequency of application of these pesticides in a farming season. This will help prevent the use of unapproved or banned pesticides as well as reduce the amounts of pesticide residues in the environment. If possible, the Quality Control Company Limited (QCC) of Ghana COCOBOD and the Government of Ghana should institute award systems and pay premium prices on cocoa beans from communities with low or non-detectable levels of unapproved pesticide residues to encourage compliance to good agricultural practices.

\section{Abbreviations}

ANOVA, Analysis of variance; CODAPEC, National Cocoa Disease and Pest Control Programme; CP, Gas Chromatograph; DDE, Dichlorodiphenyldichloroethylene; DDT, dichlorodiphenyltrichloroethane; ECD, electron capture detector; EU, European Union; GSA, Ghana Standard Authority; HCH, Hexachlorocyclohexane; MRLs, maximum residue levels; ND, below limit of reporting; OCs, Organochlorine pesticides; S1, Nkrankwanta; S2, Diabaa; S3, Krakrom; S4, Kwakuanya; SPSS, Statistical Package for Social Sciences; WHO, World Health Organization.

\section{Competing interests}

The authors declare that they have no competing interest.

\section{Authors' contributions}

$\mathrm{EDO}, \mathrm{FMBY}$ and $\mathrm{CG}$ designed the study and wrote the protocol, EDO collected data and conducted data analysis, FMBY and EDO, drafted the manuscript, and FMBY reviewed and edited the manuscript as well as serving as the corresponding author. All authors read and approved the final manuscript.

\section{Acknowledgment}

The authors express their profound gratitude to the Pesticide Residue Laboratory of Ghana Standards Authority in Ghana for logistical assistance in the analytical work.

Received: 29 February 2016 Accepted: 21 June 2016

Published online: 01 July 2016

\section{References}

Adeyemi D, Anyakora C, Ukpo G, Adedayo A, Darko G. Evaluation of the levels of organochlorine pesticide residues in water samples of Lagos Lagoon using solid phase extraction method. J Environ Chem Ecotoxicol. 2011;3(6):160166. Retrieved from http://www.academicjournals.org/journal/JECE/articleabstract/13D01A41850.

Adu-kumi S, Kawano M, Shiki Y, Yeboah PO, Carboo D, Pwamang J, Morita M. Organochlorine pesticides (OCPs), dioxin-like polychlorinated biphenyls (dlP(Bs), polychlorinated dibenzo- $p$-dioxins and polychlorinated dibenzo furans (PCDD/Fs) in edible fish from Lake Volta, Lake Bosumtwi and Weija Lake in Ghana. Chemosphere. 2010;81(6):675-84. doi:10.1016/j.chemosphere. 2010.08.018.

Afful S, Anim AK, Serfor-Armah Y Spectrum of Organochlorine Pesticide Residues in Fish Samples from the Densu Basin. Res J Environ Earth Sci. 2010;2(3):133-8. 
Afrane G, Ntiamoah A. Use of pesticides in the cocoa industry and their impact on the environment and the food chain. In: Stoytcheva M, editor. Pesticides in the modern world-risks and benefits. InTech; 2011. pp. 51-68. doi:10.5772/ 17921. Retrieved from http://www.intechopen.com/books/pesticides-in-themodern-world-risks-and-benefits/use-of-pesticides-in-thecocoa-industry-andtheir-impact-on-the-environment-and-the-food-chain.

Agbeve SK, Osei-Fosu P, Carboo D. Levels of organochlorine pesticide residues in Mondia whitei, a medicinal plant used in traditional medicine for erectile dysfunction in Ghana. Int J Adv Agric Res. 2014;1:9-16.

Agyen KE. Pesticide residues and levels of some metals in soils and cocoa beans in selected farms in the Kade area of the Eastern Region of Ghana. Ghana. (A published Master's thesis), Kwame Nkrumah University of Science and Technology, KNUST, Kumasi, Ghana. 2011. Retrieved from http://hdl.handle. net/123456789/4081.

Ahlborg UG, Lipworth L, Titus-Ernstoff L, Hsieh CC, Hanberg A, Baron J, Trichopoulos D, Adami HO. Organochlorine compounds in relation to breast cancer, edometrial cancer, and endometriosis: an assessment for the biological and epidemiological evidence. Crit Rev Toxicol. 1995;25(6):463531. doi:10.3109/10408449509017924.

Aikpokpodion P, Lajide L, Aiyesanmi AF, Lacorte S. Residues of Dichlorodiphenyltrichloroethane (DDT) and its Metabolites in Cocoa Beans from Three Cocoa Ecological Zones in Nigeria. Eur J Appl Sci. 2012;4(2):52-7.

Amoah P, Drechsel P, Abaidoo RC, Ntow WJ. Pesticide and pathogen contamination of vegetables in Ghana's urban markets. Arch Environ Contam Toxicol. 2006;50:1-6. doi:10.1007/s00244-004-0054-8.

Apau J, Dodoo D. Lindane and propoxur residues in cocoa from Central region of Ghana. J Sci Technol. 2010;30(3):3-8. doi:10.4314/just.v30i3.64624.

Asiedu E. Pesticide contamination of fruits and vegetables - a market-basket survey from selected regions in Ghana. (A published master's thesis). University of Ghana, Accra, Ghana. 2013. Retrieved from http://hdl.handle. net/123456789/5569.

Bempah CK, Donkor AK. Pesticide residues in fruits at the market level in Accra Metropolis, Ghana. A preliminary study. Environ Monit Assess. 2011;175(1-4): 551-61. doi:10.1007/s10661-010-1550-0.

Bempah CK, Buah-Kwofie A, Denutsui D, Asomaning J, Osei-Tutu A. Monitoring of pesticide residues in fruits and vegetables and related health risk assessment in Kumasi Metropolis, Ghana. Res J Environ Earth Sci. 2011a;3(6):761-71.

Bempah CK, Donkor A, Yeboah PO, Dubey B, Osei-Fosu P. A preliminary assessment of consumer's exposure to organochlorine pesticides in fruits and vegetables and the potential health risk in Accra Metropolis, Ghana. Food Chem. 2011b;128(4):1058-65. doi:10.1016/j.foodchem.2011.04.013.

Boakye S. Levels of selected pesticide residues in cocoa beans from Ashanti and Brong Ahafo regions of Ghana. (A published master's thesis), Kwame Nkrumah University of Science and Technology, KNUST, Kumasi, Ghana. 2012. Retrieved from http://hdl.handle.net/123456789/5770.

Botchway F. Analysis of pesticide residues in Ghana's exportable cocoa. A higher certificate project submitted to Institute of Science and Tchnology London, UK. 2000. p. 44-5.

Botwe BO. Organochlorine pesticide residues contamination of Ghanaian market vegetables. 2007. p. 1-6.

Botwe BO, Ntow WJ, Nyarko E, Kelderman P. Evaluation of Occupational and Vegetable Dietary Exposures to Current-Use Agricultural Pesticides in Ghana. In: Pesticides-Recent Trends in Pesticide Residue Assay. InTech; 2012. pp. 46 62. doi:10.5772/80105

Clarke EEK, Levy LS, Spurgeon A, Calvert IA. The problems associated pesticide use by irrigation workers in Ghana. Occup Med (Chic III). 1997;47(5):301-8. doi:10.1093/occmed/47.5.301.

Daanu PB. Concentration of pesticide residues in fermented dried cocoa beans in Asukese and its environs in the Tano north district of Brong Ahafo region, Ghana. (A published master's thesis), Kwame Nkrumah University of Science and Technology, KNUST, Kumasi, Ghana. 2011. Retrieved from http://hdl. handle.net/123456789/4750.

Darko G, Acquaah SO. Levels of organochlorine pesticides residues in meat. Int J Environ Sci Technol. 2007:4(4):521-4. doi:10.1007/BF03325989.

Darko G, Akoto O, Oppong C. Persistent organochlorine pesticide residues in fish, sediments and water from Lake Bosomtwi, Ghana. Chemosphere. 2008;72: 21-4. doi:10.1016/j.chemosphere.2008.02.052.

Dikshith TSS. Safe use of chemicals. A practical guide. Boca Raton, Florida, USA: CRC Press (Taylor \& Francis Group); 2008.
Frimpong KS, Yeboah P, Fletcher JJ, Adomako D, Osei-fosu P, Acheampong K. Organochlorine pesticides levels in fermented dried cocoa beans produced in Ghana. Elixir Agric. 2012a;44:7280-4.

Frimpong KS, Yeboah P, Fletcher JJ, Adomako D, Pwamang J. Assessment of organochlorine pesticides residues in cocoa beans from Ghana. Elixir Food Sci. 2012b;50:10257-61.

Frimpong KS, Yeboah PO, Fletcher JJ, Pwamang J, Adomako D. Assessment of synthetic pyrethroids pesticides residues in cocoa beans from Ghana. Elixir Food Sci. 2012c;49:9871-5.

Frimpong KS, Yeboah PO, Fletcher JJ, Pwamang J, Adomako D. Multi-residue levels of Organophosphorous pesticides in cocoa beans produced from Ghana. Elixir Food Sci. 2012d;47:8721-5.

Ghana Statistical Service. 2010 Population and Housing Census: District Analytical Report of Dormaa West. 2014.

Hogarh JN, Seike N, Kobara Y, Ofosu-Budu GK, Carboo D, Masunaga S. Atmospheric burden of organochlorine pesticides in Ghana. Chemosphere. 2014;102:1-5. doi:10.1016/j.chemosphere.2013.10.019.

Idowu GA, Aiyesanmi AF, Owolabi BJ. Organochlorine pesticide residue levels in river water and sediment from cocoa-producing areas of Ondo State central senatorial district, Nigeria. J Environ Chem Ecotoxicol. 2013;5(9):242-9. doi:10. 5897/JECE2013.0293.

International Cocoa Organization (ICCO). Progress Report Action Programme on Pesticides, ICCO Executive Committee Meeting, EBRD Offices, London. Italy: 2007.

Kaminaga K. The Positive List System in Japan and Our Approach to the Issues of Pesticide Residues in Cocoa. Chocolate and Cocoa Association of Japan (CCAJ). International Workshop on the Safe Use of Pesticides in Cocoa, Kuala Lumpur, Malaysia. 2011.

Kuranchie-Mensah H, Atiemo MS, Maud L, Palm LMND, Blankson-Arthur S, Tutu $A O$, Fosu P. Determination of organochlorine pesticide residue in sediment and water from the Densu river basin, Ghana. Chemosphere. 2012;86(3):28692. doi:10.1016/j.chemosphere.2011.10.031.

Leena S, Choudhary SK, Singh PK. Pesticide concentration in water and sediment of River Ganga at selected sites in middle Ganga plain. Int J Environ Sci. 2012;3(1):260-74. doi:10.6088/ijes.2012030131026.

Miles A, Mark K, Ricca A, Robert A, Anthony G, James A. Organochlorine contaminants if fishes from coastal waters West of Amukta pass, Aleutian islands, Alaska, USA. Environ Toxicol Chem. 2009:28(8):1643-54.

Ntow WJ. Pesticide residues in Volta Lake, Ghana. Lakes Reserv Res Manag. 2005; 10(4):243-8. doi:10.1111/j.1440-1770.2005.00278.x.

Olayinka Al. Levels of Organochlorine Pesticides (OCPS) Residue in Selected Cocoa Farms in Ilawe - Ekiti, Ekiti State, Nigeria. Open J Anal Chem Res. 2013;1(3):52-8. doi:10.12966/ojacr.11.02.2013.

Owusu-Ansah E, Koranteng-Addo JE, Boamponsem LK, Menlah E, Abole E. Assessment of Lindane pesticide residue in Cocoa beans in the Twifo Praso district of Ghana. J Chem Pharm Res. 2010;2(4):580-7.

Sarfo JE. Behavioural responses of cocoa mirids, sahlbergella singularis hagl and distantiella theobroma dist. (heteroptera:miridae), to sex pheromones. (A published Doctoral thesis), University of Greenwich, London, England. 2013. Retrieved from http://gala.gre.ac.uk/id/eprint/10335.

Sosan MB, Akingbohungbe $A E$, Ojo IAO, Durosinmi MA. Insecticide residues in the blood serum and domestic water source of cacao farmers in Southwestern Nigeria. Chemosphere. 2008;72(5):781-4. doi:10.1016/j. chemosphere.2008.03.015.

WHO. Guidelines for Drinking-water Quality: Vol. 2 Health and other Supporting Criteria. 2nd ed. Geneva: World Health Organization; 1996.

William JN, Tagoe LM, Drechsel P, Kelderman P, Gijzen HJ, Nyarko E. Cumulation of persistent organochlorine contaminants in milk and serum of farmers from Ghana. Environ Reserv. 2008;106(1):17-26. doi:10.1016/j.envres.2007.05.020. 